\title{
Review
}

\section{Long-term complications and side effects after allogeneic hematopoietic stem cell transplantation: an update}

\author{
B Mohty ${ }^{1}$ and M Mohty M $^{2,3,4}$ \\ ${ }^{1}$ Centre Hospitalier Universitaire de Geneve, Service d'hématologie, Geneva, Switzerland; ${ }^{2}$ Centre Hospitalier et Universitaire \\ $(\mathrm{CHU})$ de Nantes, Hématologie Clinique, Centre d'Investigation Clinique en Cancérologie (Cl2C), CHU de Nantes, Nantes, \\ France; ${ }^{3}$ Université de Nantes and INSERM CRNCA UMR 892, Nantes, France and ${ }^{4}$ Acute Leukemia Working Party (ALWP) of \\ the European group for Blood and Marrow Transplantation, Paris, France
}

\begin{abstract}
Allogeneic hematopoietic stem cell transplantation (allo-HSCT) is an effective therapy for various malignant and non-malignant diseases. Many patients have now been followed for two or three decades posttransplant and are presumed to be cured. With the tremendous advances achieved in terms of supportive care, it is reasonable to expect outcomes to improve steadily and consequently increasing numbers of transplant survivors will be facing life after the initial transplant experience. Although long-term allo-HSCT survivors generally enjoy good health, for many others, cure or control of the underlying disease is not accompanied by full restoration of health. The burden of long-term morbidity borne by allo-HSCT survivors is substantial, and long-term follow-up of patients who received allo-HSCT is now widely recommended. Immediate survival is no longer the sole concern after allo-HSCT. The goals should also include complete recovery of the overall health status with normal physical and psychological functioning. Long-term side effects after allo-HSCT include non-malignant organ or tissue dysfunction, changes in quality of life, infections related to abnormal immune reconstitution and secondary cancers. Many of these can be attributed to the deleterious effects of chronic graft-versus-host disease. The aims of this review are to provide an update on the recent research evidence in the field. Blood Cancer Journal (2011) 1, e16; doi:10.1038/bcj.2011.14; published online 29 April 2011
\end{abstract}

Keywords: allogeneic hematopoietic stem cell transplantation; graft versus host disease; late effects; survivorship; quality of life; malignant complications

\section{Introduction}

Allogeneic hematopoietic stem cell transplantation (allo-HSCT) is an effective therapy for various malignant and non-malignant diseases. Many patients have now been followed for two or three decades post-transplant and are presumed to be cured. At present, the allo-HSCT transplant activity is steadily increasing worldwide. This increase is mainly driven by the use of the so-called reduced intensity conditioning (RIC) regimens, and because of access to alternative stem cell sources from human leukocyte antigen-matched or mismatched unrelated adult donors and from cord blood. A recent analysis, published from the Seattle Group, found a substantial reduction in the hazard of death over the past decade when comparing the period from 1993-1997 to 2003-2007. Improved outcomes appear to be related to reductions in organ damage, infection and severe

Correspondence: Dr M Mohty, Hématologie Clinique, $\mathrm{CHU}$ de Nantes, Université de Nantes and INSERM CRNCA UMR 892, Place A. Ricordeau, F-44093 Nantes Cedex, France.

E-mail: mohamad.mohty@univ-nantes.fr

Received 6 February 2011; accepted 24 February 2011 acute graft-versus-host disease (GVHD). ${ }^{1}$ With the tremendous advances achieved in terms of supportive care, it is reasonable to expect outcomes to improve substantially, and consequently increasing numbers of transplant survivors will be facing life after the initial transplant experience. Although long-term alloHSCT survivors generally enjoy good health, for many others cure or control of the underlying disease is not accompanied by full restoration of health. ${ }^{2}$ When looking to all-cause mortality in a cohort of almost 1500 patients who survived 2 or more years after allo-HSCT, mortality rates remain twice as high as that of the general population among 15-year survivors of allo-HSCT, and that the survivors face challenges affecting their health and well-being. Relapse of primary disease $(29 \%)$ and chronic GVHD (cGVHD; 22\%) were the leading causes of premature death. ${ }^{3}$ Moreover, in patients who have survived for at least 5 years after allo-HSCT without recurrence of the original disease, life expectancy is still not fully restored. Mortality rates remained four- to ninefold higher than those expected in the general population for at least 30 years after transplantation, providing an estimated $30 \%$ lower life expectancy, regardless of current age. In rank order, the leading causes of excess deaths were second malignancies and recurrent disease, followed by infections, cGVHD, respiratory diseases and cardiovascular diseases. ${ }^{4}$ The burden of long-term morbidity borne by alloHSCT survivors is substantial, and long-term follow-up of patients who received allo-HSCT is now widely recommended. Allo-HSCT survivors were twice as likely as siblings to develop a chronic condition, and 3.5 times to develop severe/lifethreatening conditions, whereas allo-HSCT survivors with cGVHD were 4.7 times as likely to develop severe/lifethreatening conditions. ${ }^{5}$ In terms of health-care utilization by long-term survivors after allo-HSCT, more than $95 \%$ of the patients reported medical contact and the prevalence of general physical examination increased with time, highlighting the need for increased awareness of long-term side effects after allo-HSCT. ${ }^{6}$

At present, immediate survival is no longer the sole concern after allo-HSCT, as many patients can survive the acute complications of the procedure and remain free of their original disease for several years. As a matter of fact, the primary aim of allo-HSCT is the cure from the primary disease. However, the goals should also include complete recovery of the health status with normal physical and psychological functioning but also normal family and social integration with good subjective well-being. Long-term side effects after allo-HSCT include nonmalignant organ or tissue dysfunction, changes in quality of life, infections related to abnormal immune reconstitution and secondary cancers. Many of these can be attributed to the deleterious effects of cGVHD. Almost all organs and tissues can 


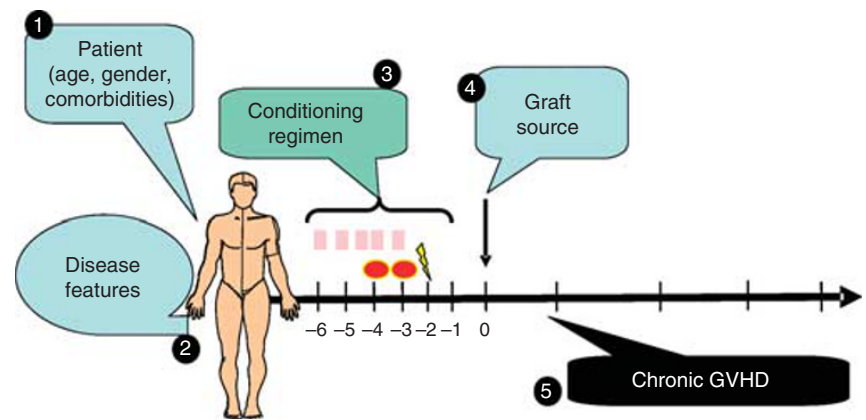

Figure 1 Long-term side effects after allo-SCT: major risk factors.

be the target for the long-term side effects after allo-HSCT. Nevertheless, one should also take into account the common diseases or other comorbidities that the patient might have had before transplantation. Also, one should consider the issues of physiological aging and the impact of lifestyle and environment. Among the transplant community, it is common to define all events occurring beyond 3 months after allo-HSCT as late complications, and separate them into delayed (from 3 months to 2 years), late (2-10 years) and very late events ( $>10$ years). ${ }^{7}$ Figure 1 summarizes the different steps that may be considered as risk factors for long-term side effects after allo-HSCT. These risk factors can be related to the patient and disease features or to the transplant technique itself, including the choice of conditioning regimen, the choice of the graft source and the occurrence of long-term cGVHD. Despite an ever-growing knowledge of the natural history of the side effects of allogeneic bone marrow transplantation, long-term complications and the features of cGVHD symptoms are heterogeneous in nature, time of onset, duration and severity. The latter parameters may depend on the intensity of the conditioning regimen and immunosuppressive therapies used. The aims of this review are not to provide a comprehensive list of the different late complications occurring after allo-HSCT, but rather an update on the recent research evidence in the field. Recommended screening and preventive practices were published elsewhere and will not be discussed here. ${ }^{8}$ Also, specific complications encountered in the pediatric allo-HSCT population, will not be addressed.

\section{Role of the conditioning regimen}

Intensity of the conditioning regimen, especially the use of full-dose myeloablative total body irradiation (TBI) is likely to have a major role in the onset of diverse late complications after allo-HSCT. Several studies have demonstrated an impact of TBI on cataract formation with an incidence of $<20 \%$ in the no-TBI group versus more than $80 \%$ in the single-dose TBI group.., 10 Spermatogenesis provides another example of the deleterious impact of high-dose $\mathrm{TBI}$, with $85 \%$ of the patients receiving TBI developing azoospermia versus $51 \%$ in the no-TBI group. ${ }^{11}$ The incidence of diabetes and hypertension is also significantly increased after allo-HSCT as compared with patient receiving autologous transplantation or to their siblings. Besides, the use of radiation therapy appears to be deleterious especially when it comes to diabetes. ${ }^{12}$ As non-myeloablative or RIC regimens are being increasingly used in the allogeneic setting, one might question whether the use of RIC will reduce long-term toxicity after allo-HSCT ? At present, it is well established that RIC can reduce short-term acute toxicity. However, it has been proven that the probability of cGVHD is not reduced after RIC because RIC regimens are mainly used in older patients, in more advanced diseases with peripheral blood stem cells being the main graft source. ${ }^{13-15}$ In one study assessing chronic kidney disease in patients that had received RIC versus myeloablative regimens, there were no significant differences in term of renal complications. ${ }^{16}$

\section{Role of the stem cell source and chronic GVHD}

The graft source has a major role in long-term side effects, especially cGVHD. A large meta-analysis that included more than 1100 patients from nine international randomized trials, demonstrated a significantly higher incidence of extensive cGVHD when using granulocyte colony-stimulating factormobilized peripheral blood stem cells versus bone marrow. On the other hand, the incidence and severity of cGVHD is likely lower after unrelated cord blood transplantation. ${ }^{17}$ Chronic GVHD, and its different target organs (Table 1), is one of the most serious consequence of allo-HSCT, involving many physical, human, emotional, societal, financial and intellectual resources for the patients and caregivers. Indeed, active cGVHD has a significant impact on many aspects of the overall health status. In multivariable analyses, subjects with active cGVHD were more likely to report adverse general health, mental health, functional impairments, activity limitation and pain than were those with no history of CGVHD. However, health status did not differ between those with resolved CGVHD and those who never had cGVHD. Also, the percentage of chronic GVHD patients with poor general health status will remain very high at any time after transplantation. ${ }^{18}$ Avascular necrosis is one example demonstrating that cGVHD and its corollary of long-term immunosuppressive therapy are significant risk factors for this complication. ${ }^{19}$ The lung is another important target for cGVHD with different complications being described thus far. The non-infectious complications can be divided into the bronchiolitis obliterans syndrome, the bronchiolitis obliterans-organizing pneumonia and the idiopathic pneumonia syndrome. ${ }^{20}$ The incidence of pulmonary non-infectious complications in patients surviving more than 3 months after allo-HSCT transplant is around $10 \%$ at 2 years and the outcome of patients with cGVHD who develop pulmonary complications is significantly worse than cGVHD patients without pulmonary complications. ${ }^{21}$ Bronchiolitis obliterans syndrome is usually considered as a severe pulmonary manifestation affecting the small airways. Its incidence can range from 2 to $14 \%$ and the overall survival is around $13 \%$ at 5 years. The clinical presentation is often insidious, although some patients may have dry cough, progressive dyspnea or wheezing, without 
Table 1 Signs and symptoms of chronic GVHD (reproduced from Filipovich et al. ${ }^{24}$ )

\begin{tabular}{|c|c|c|c|c|}
\hline Organ or site & $\begin{array}{l}\text { Diagnostic (sufficient to } \\
\text { establish the diagnosis of } \\
\text { chronic GVHD) }\end{array}$ & $\begin{array}{l}\text { Distinctive (seen in chronic } \\
\text { GVHD, but insufficient alone } \\
\text { to establish a diagnosis of } \\
\text { chronic GVHD) }\end{array}$ & Other features ${ }^{a}$ & $\begin{array}{l}\text { Common (seen with both } \\
\text { acute and chronic GVHD) }\end{array}$ \\
\hline Skin & $\begin{array}{l}\text { Poikiloderma } \\
\text { Lichen planus-like features } \\
\text { Sclerotic features } \\
\text { Morphea-like features } \\
\text { Lichen sclerous-like features }\end{array}$ & Depigmentation & $\begin{array}{l}\text { Sweat impairment } \\
\text { Ichthyosis } \\
\text { Keratosis pilaris } \\
\text { Hypopigmentation } \\
\text { Hyperpigmentation }\end{array}$ & $\begin{array}{l}\text { Erythema } \\
\text { Maculopapular rash } \\
\text { Pruritus }\end{array}$ \\
\hline Nails & & $\begin{array}{l}\text { Dystrophy } \\
\text { Longitudinal ridging, splitting, } \\
\text { or brittle features } \\
\text { Onycholysis } \\
\text { Pterygium unguis } \\
\text { Nail loss (usually symmetric; } \\
\text { affects most nails) }\end{array}$ & & \\
\hline $\begin{array}{l}\text { Scalp and } \\
\text { body hair }\end{array}$ & & $\begin{array}{l}\text { New onset of scarring or } \\
\text { nonscarring scalp alopecia } \\
\text { (after recovery from } \\
\text { chemoradiotherapy) } \\
\text { Scaling, papulosquamous lesions }\end{array}$ & $\begin{array}{l}\text { Thinning scalp hair, typically } \\
\text { patchy, coarse, or dull (not } \\
\text { explained by endocrine or } \\
\text { other causes) } \\
\text { Premature gray hair }\end{array}$ & \\
\hline Mouth & $\begin{array}{l}\text { Lichen-type features } \\
\text { Hyperkaratotic plaques } \\
\text { Restriction of mouth opening } \\
\text { from sclerosis }\end{array}$ & $\begin{array}{l}\text { Xerostomia } \\
\text { Mucocele } \\
\text { Mucosal atrophy } \\
\text { Pseudomembranes }^{\text {b }} \\
\text { Ulcers }^{b}\end{array}$ & & $\begin{array}{l}\text { Gingivitis } \\
\text { Mucositis } \\
\text { Erythema } \\
\text { Pain }\end{array}$ \\
\hline Eyes & & $\begin{array}{l}\text { New-onset dry, gritty, or } \\
\text { painful eyes } \\
\text { Cicatricial conjunctivitis }^{c} \\
\text { Keratoconjunctivitis sicca } \\
\text { Confluent areas of punctuate } \\
\text { keratopathy }\end{array}$ & $\begin{array}{l}\text { Photophobia } \\
\text { Periorbital } \\
\text { Hyperpigmentation } \\
\text { Blepharitis (erythema of } \\
\text { the eyelids with edema) }\end{array}$ & \\
\hline Genitalia & $\begin{array}{l}\text { Lichen planus-like features } \\
\text { Vaginal scarring or stenosis }\end{array}$ & $\begin{array}{l}\text { Erosions }^{\mathrm{b}} \\
\text { Fissures }^{\mathrm{b}} \\
\text { Ulcers }^{\mathrm{b}}\end{array}$ & & \\
\hline Gl tract & $\begin{array}{l}\text { Esophageal web } \\
\text { Strictures or stenosis in the } \\
\text { upper to mid third of the } \\
\text { esophagus }^{b}\end{array}$ & & $\begin{array}{l}\text { Exocrine } \\
\text { pancreatic insufficiency }\end{array}$ & $\begin{array}{l}\text { Anorexia } \\
\text { Nausea } \\
\text { Vomiting } \\
\text { Diarrhea } \\
\text { Weight loss } \\
\text { Failure to thrive } \\
\text { (infants and children) }\end{array}$ \\
\hline Liver & & & & $\begin{array}{l}\text { Total bilirubin, alkaline } \\
\text { phosphatases }>2 \times \\
\text { upper limit of normal } \\
\text { ALT or AST }>2 \times \text { upper }^{\text {limit of normal }}{ }^{b}\end{array}$ \\
\hline Lung & $\begin{array}{l}\text { Bronchiolitis obliterans } \\
\text { diagnosed with lung biopsy }\end{array}$ & $\begin{array}{l}\text { Bronchiolitis obliterans diagnosed } \\
\text { with PFTs and radiology }\end{array}$ & & $\mathrm{BOOP}$ \\
\hline $\begin{array}{l}\text { Muscles, } \\
\text { fascia, joints }\end{array}$ & $\begin{array}{l}\text { Fascilitis } \\
\text { Joint stiffness or contractures } \\
\text { secondary to sclerosis }\end{array}$ & Myositis or polymyositis ${ }^{\mathrm{C}}$ & $\begin{array}{l}\text { Edema } \\
\text { Muscle cramps } \\
\text { Arthralgia or arthritis }\end{array}$ & \\
\hline $\begin{array}{l}\text { Hematopoietic } \\
\text { and immune }\end{array}$ & & & $\begin{array}{l}\text { Thrombocytopenia } \\
\text { Eosinophilia } \\
\text { Lymphopenia } \\
\text { Hypo or } \\
\text { hypergammaglobulinemia } \\
\text { Autoantibodies (AlHA and ITP) }\end{array}$ & \\
\hline Other & & & $\begin{array}{l}\text { Pericardial or pleural effusions } \\
\text { Ascites } \\
\text { Peripheral neuropathy } \\
\text { Nephrotic syndrome } \\
\text { Myasthenia gravis } \\
\text { Cardiac conduction } \\
\text { abnormality or cardiomyopathy }\end{array}$ & \\
\hline
\end{tabular}

Abbreviations: AlHA, autoimmune hemolytic anemia; ALT, alanine aminotransferase; AST, aspartate aminotransferase; BOOP, bronchiolitis obliterans-organizing pneumonia; GVHD, graft-versus-host disease; ITP, idiopathic thrombocytopenic purpura; PFTs, pulmonary function tests. ${ }^{a}$ Can be acknowledged as part of the chronic GVHD symptomatology if the diagnosis is confirmed.

bIn all cases, infection, drug effects, malignancy, or other causes must be excluded.

'Diagnosis of chronic GVHD requires biopsy or radiology confirmation (or Schirmer test for eyes).

fever. The diagnosis of bronchiolitis obliterans syndrome is based on an expiratory flow $<75 \%$ of predicted in addition to specific features on high-resolution computed tomography scan and absence of infection in the respiratory tract. ${ }^{22,23}$ An increasing body of data could show a strong association between bronchiolitis obliterans syndrome and pulmonary cGVHD. ${ }^{24}$ 
In contrast to pulmonary complications, cardiac and vascular complications usually occur 'very late' after allo-HSCT with a relatively low magnitude of risk during the first decade. Indeed, after 20 years of follow-up, the incidence of arterial events might be as high as $22 \% .^{25,26}$ In addition to the allo-HSCT treatment itself, the usual cardiovascular risk factors such as smoking, hypertension, diabetes or obesity were shown to be significant factors for an arterial event after allo-HSCT. ${ }^{25}$ From the pathophysiological standpoint, data published in 2002 suggested that host endothelial cells are a target of alloreactive donor cytotoxic $\mathrm{T}$ cells, and there is an extensive loss of microvessels in the skin of patients with cGVHD, which may lead to tissue fibrosis, the hallmark lesion of cGVHD. ${ }^{27}$

Renal complications are also frequent after allo-HSCT with an incidence around $23 \%$ after a median time of 2.5 years after transplantation. Older age, hypertension, poor kidney function before transplantation, but also acute and cGVHD with the use of calcineurin inhibitors were shown to be risk factors for chronic kidney disease. The effect of TBI is still controversial. ${ }^{28-30}$

\section{Late secondary malignancies after allo-HSCT}

Different categories of secondary malignancies can occur after allo-HSCT, including post-transplant lymphoproliferative disorders, late relapse of the primary disease, donor-type secondary leukemia/other malignancy and de novo solid tumors. As part of this Review, we will focus on secondary solid tumors. TBI and the chemotherapeutic drugs used before allo-HSCT as part of the conditioning regimen can induce new secondary malignancies after allo-HSCT. This is attributed to the mutagenic risk of irradiation and chemotherapy, the genetic predisposition of the patient to develop cancer, prolonged immunosuppression, and in elderly patients, to age-related risk.

One of the first largest reports, including more than 1000 patients transplanted before December 1985, could show that the incidence of secondary malignancies is around $3.5 \%$ at 10 years and $12.8 \%$ at 15 years, which is 3.8 -fold higher than that of an age-matched control population. ${ }^{31}$ This study was recently updated. This update showed that the incidence of secondary malignancies continued to increase with longer follow-up time compared with age-matched control population. ${ }^{32}$ A more recent very large analysis including 28874 patients who received allo-HSCT, showed that solid cancers occurred twice more frequently than expected in the general population and this risk reached threefold among patients followed for 15 years or more. Of note, allo-HSCT survivors irradiated at young ages had increased risks of solid cancers. ${ }^{33}$ Indeed, the risk of secondary solid cancer may vary depending on the type of conditioning regimen. In a study including acute and chronic myeloid leukemia patients receiving high-dose Busulfan and cyclophosphamide conditioning, the cumulative incidence of solid cancers at 10 years was $1.2 \%$ for acute myeloid leukemia and $2.4 \%$ for chronic myeloid leukemia, which was 1.4 times higher in comparison with general population incidence rates. Significantly elevated risks were observed for tumors of the oral cavity, esophagus, lung, soft tissue and brain. Chronic GVHD was an independent risk factor for all solid cancers, and especially for cancers of the oral cavity. ${ }^{34}$ The picture may also be different when it comes to some specific cancers such as thyroid cancer in which younger age was found to be the strongest risk factor of secondary thyroid cancer. ${ }^{35}$ A joint EBMT/Seattle study showed that the cumulative incidence of breast cancer is around 5\% at 20 years and the median time to breast cancer diagnosis is around 12.5 years. Cumulative incidence was higher among survivors who received $\mathrm{TBI}$ than those who did not receive $\mathrm{TBI}$. In multivariable analysis, increased risk was associated with longer time since transplantation, use of $\mathrm{TBI}$ and younger age at transplantation. ${ }^{36}$

\section{Conclusion}

Allo-HSCT has the potential to cure a significant proportion of patients with otherwise fatal diseases. However, allo-HSCT recipients are exposed to long-term complications and side effects. All of these late complications present a great diversity in respect to frequencies, time of onset, risk factors, prevention strategies, treatment approaches and outcomes. In many patients, long-term survivorship is not accompanied by full restoration of health. The long-term side effects are usually a multifactorial and complex process, and the natural history of such late effects will likely change in the future because the transplant techniques have been changing significantly over the last three decades. Chronic GVHD remains the most challenging risk factor. A preventable death with a functioning hematopoietic allograft is not a marker of success. Patients can have a major role through engagement in health-maintenance behaviors.

The long-term goal is maintenance of health and to ensure the best possible quality of life. Establishment of a close partnership between the transplant centre, the organ-specific specialities and local primary careproviders to provide life-long counseling and prevention therapy is a key factor for the long-term success of any transplant program.

\section{Conflict of interest}

The authors declare no conflict of interest.

\section{Acknowledgements}

We would like to apologize to those colleagues whose work could not be cited because of space limitation. We thank the nursing staff for providing excellent care for our patients. MM would like also to thank the 'Région Pays de Loire', the 'Association pour la Recherche sur le Cancer (ARC)', the 'Fondation de France', the 'Fondation contre la Leucémie', the 'Agence de Biomédecine', the 'Association Cent pour Sang la Vie', the 'Association Laurette Fuguain' and the association IRGHET for their generous and continuous support for his clinical and basic research work. MM group is supported by several grants from the French national cancer institute (PHRC, INCa). We acknowledge the continuous support of the cell banking facility ('tumurotheque') of the $\mathrm{CHU}$ de Nantes.

\section{References}

1 Gooley TA, Chien JW, Pergam SA, Hingorani S, Sorror ML, Boeckh M et al. Reduced mortality after allogeneic hematopoietic-cell transplantation. N Engl J Med 2010; 363: 2091-2101.

2 Syrjala KL, Langer SL, Abrams JR, Storer BE, Martin PJ. Late effects of hematopoietic cell transplantation among 10-year adult survivors compared with case-matched controls. J Clin Oncol 2005; 23: 6596-6606.

3 Bhatia S, Francisco L, Carter A, Sun CL, Baker KS, Gurney JG et al. Late mortality after allogeneic hematopoietic cell transplantation and functional status of long-term survivors: report from the Bone Marrow Transplant Survivor Study. Blood 2007; 110: 3784-3792. 
4 Martin PJ, Counts Jr GW, Appelbaum FR, Lee SJ, Sanders JE, Deeg $\mathrm{HJ}$ et al. Life expectancy in patients surviving more than 5 years after hematopoietic cell transplantation. J Clin Oncol 2010; 28: 1011-1016.

5 Sun CL, Francisco L, Kawashima T, Leisenring W, Robison LL, Baker KS et al. Prevalence and predictors of chronic health conditions after hematopoietic cell transplantation: a report from the Bone Marrow Transplant Survivor Study. Blood 2010; 116: 3129-3139; quiz 3377.

6 Shankar SM, Carter A, Sun CL, Francisco L, Baker KS, Gurney JG et al. Health care utilization by adult long-term survivors of hematopoietic cell transplant: report from the Bone Marrow Transplant Survivor Study. Cancer Epidemiol Biomarkers Prev 2007: 16: 834-839.

7 Tichelli A, Rovo A, Gratwohl A. Late pulmonary, cardiovascular, and renal complications after hematopoietic stem cell transplantation and recommended screening practices. Hematology Am Soc Hematol Educ Program 2008, 125-133.

8 Rizzo JD, Wingard JR, Tichelli A, Lee SJ, Van Lint MT, Burns LJ et al. Recommended screening and preventive practices for long-term survivors after hematopoietic cell transplantation: joint recommendations of the European Group for Blood and Marrow Transplantation, the Center for International Blood and Marrow Transplant Research, and the American Society of Blood and Marrow Transplantation. Biol Blood Marrow Transplant 2006; 12: $138-151$

9 Belkacemi $Y$, Labopin M, Vernant JP, Prentice HG, Tichelli A Schattenberg $\mathrm{A}$ et al. Cataracts after total body irradiation and bone marrow transplantation in patients with acute leukemia in complete remission: a study of the European Group for Blood and Marrow Transplantation. Int J Radiat Oncol Biol Phys 1998; 41: 659-668.

10 Tichelli A, Gratwohl A, Egger T, Roth J, Prunte A, Nissen C et al. Cataract formation after bone marrow transplantation. Ann Intern Med 1993; 119: 1175-1180.

11 Rovo A, van Lint MT, Aljurf M, Salooja N, Sucak G, Hunter A et al. Spermatogenesis recovery in male survivors after HSCT: evidence for graft-versus-testis effect, on behalf of the Late Effects Working Party - EBMT. Bone Marrow Transplant 2010; 45(Suppl 2): S4 (abstract 92)

12 Baker KS, Ness KK, Steinberger J, Carter A, Francisco L, Burns LJ et al. Diabetes, hypertension, and cardiovascular events in survivors of hematopoietic cell transplantation: a report from the bone marrow transplantation survivor study. Blood 2007; 109: 1765-1772.

13 Mohty M, Bay JO, Faucher C, Choufi B, Bilger K, Tournilhac O et al. Graft-versus-host disease following allogeneic transplantation from HLA-identical sibling with antithymocyte globulinbased reduced-intensity preparative regimen. Blood 2003; 102 470-476.

14 Mohty M, Kuentz M, Michallet M, Bourhis JH, Milpied N, Sutton L et al. Chronic graft-versus-host disease after allogeneic blood stem cell transplantation: long-term results of a randomized study. Blood 2002; 100: 3128-3134.

15 Mohty M, Bilger K, Jourdan E, Kuentz M, Michallet M, Bourhis JH et al. Higher doses of CD34+ peripheral blood stem cells are associated with increased mortality from chronic graft-versus-host disease after allogeneic HLA-identical sibling transplantation. Leukemia 2003; 17: 869-875.

16 Al-Hazzouri A, Cao Q, Burns LJ, Weisdorf DJ, Majhail NS. Similar risks for chronic kidney disease in long-term survivors of myeloablative and reduced-intensity allogeneic hematopoietic cell transplantation. Biol Blood Marrow Transplant 2008; 14: 658-663.

17 Narimatsu H, Miyakoshi S, Yamaguchi T, Kami M, Matsumura T, Yuji K et al. Chronic graft-versus-host disease following umbilical cord blood transplantation: retrospective survey involving 1072 patients in Japan. Blood 2008; 112: 2579-2582.

18 Fraser Cl, Bhatia S, Ness K, Carter A, Francisco L, Arora M et al. Impact of chronic graft-versus-host disease on the health status of hematopoietic cell transplantation survivors: a report from the Bone Marrow Transplant Survivor Study. Blood 2006; 108 2867-2873.

19 Campbell S, Sun CL, Kurian S, Francisco L, Carter A, Kulkarni S et al. Predictors of avascular necrosis of bone in long-term survivors of hematopoietic cell transplantation. Cancer 2009; 115: 4127-4135.
20 Yoshihara S, Yanik G, Cooke KR, Mineishi S. Bronchiolitis obliterans syndrome (BOS), bronchiolitis obliterans organizing pneumonia (BOOP), and other late-onset noninfectious pulmonary complications following allogeneic hematopoietic stem cell transplantation. Biol Blood Marrow Transplant 2007; 13: 749-759.

21 Patriarca F, Skert C, Bonifazi F, Sperotto A, Fili C, Stanzani M et al. Effect on survival of the development of late-onset non-infectious pulmonary complications after stem cell transplantation. Haematologica 2006; 91: 1268-1272.

22 Afessa B, Litzow MR, Tefferi A. Bronchiolitis obliterans and other late onset non-infectious pulmonary complications in hematopoietic stem cell transplantation. Bone Marrow Transplant 2001; 28: $425-434$.

23 Williams KM, Chien JW, Gladwin MT, Pavletic SZ. Bronchiolitis obliterans after allogeneic hematopoietic stem cell transplantation. JAMA 2009; 302: 306-314.

24 Filipovich AH, Weisdorf D, Pavletic S, Socie G, Wingard JR, Lee SJ et al. National Institutes of Health consensus development project on criteria for clinical trials in chronic graft-versus-host disease: I. Diagnosis and staging working group report. Biol Blood Marrow Transplant 2005; 11: 945-956.

25 Tichelli A, Bucher C, Rovo A, Stussi G, Stern M, Paulussen M et al. Premature cardiovascular disease after allogeneic hematopoietic stem-cell transplantation. Blood 2007; 110: 3463-3471.

26 Tichelli A, Bhatia S, Socie G. Cardiac and cardiovascular consequences after haematopoietic stem cell transplantation. Br J Haematol 2008; 142: 11-26.

27 Biedermann BC, Sahner S, Gregor M, Tsakiris DA, Jeanneret C, Pober JS et al. Endothelial injury mediated by cytotoxic $\mathrm{T}$ lymphocytes and loss of microvessels in chronic graft versus host disease. Lancet 2002; 359: 2078-2083.

28 Kersting S, Hene RJ, Koomans HA, Verdonck LF. Chronic kidney disease after myeloablative allogeneic hematopoietic stem cell transplantation. Biol Blood Marrow Transplant 2007; 13: 1169-1175.

29 Hingorani S, Guthrie KA, Schoch G, Weiss NS, McDonald GB. Chronic kidney disease in long-term survivors of hematopoietic cell transplant. Bone Marrow Transplant 2007; 39: 223-229.

30 Choi M, Sun CL, Kurian S, Carter A, Francisco L, Forman SJ et al. Incidence and predictors of delayed chronic kidney disease in long-term survivors of hematopoietic cell transplantation. Cancer 2008; 113: 1580-1587.

31 Kolb HJ, Socie G, Duell T, Van Lint MT, Tichelli A, Apperley JF et al. Malignant neoplasms in long-term survivors of bone marrow transplantation. Late Effects Working Party of the European Cooperative Group for Blood and Marrow Transplantation and the European Late Effect Project Group. Ann Intern Med 1999; 131: 738-744.

32 Heilmeier B, Stowasser N, Socie G, van Limit MT, Tichelli A, Salooja $\mathrm{N}$ et al. Malignant neoplasms in long-term survivors of bone marrow transplantation - follow up. Blood (ASH Annu Meet Abstr) 2008; 112: 453.

33 Rizzo JD, Curtis RE, Socie G, Sobocinski KA, Gilbert E, Landgren O et al. Solid cancers after allogeneic hematopoietic cell transplantation. Blood 2009; 113: 1175-1183.

34 Khan FM, Sy S, Louie P, Ugarte-Torres A, Berka N, Sinclair GD et al. Genomic instability after allogeneic hematopoietic cell transplantation is frequent in oral mucosa, particularly in patients with a history of chronic graft-versus-host disease, and rare in nasal mucosa. Blood 2010; 116: 1803-1806.

35 Cohen A, Rovelli A, Merlo DF, van Lint MT, Lanino E, Bresters D et al. Risk for secondary thyroid carcinoma after hematopoietic stem-cell transplantation: an EBMT Late Effects Working Party Study. J Clin Oncol 2007; 25: 2449-2454.

36 Friedman DL, Rovo A, Leisenring W, Locasciulli A, Flowers ME, Tichelli A et al. Increased risk of breast cancer among survivors of allogeneic hematopoietic cell transplantation: a report from the FHCRC and the EBMT-Late Effect Working Party. Blood 2008; 111: 939-944.

This work is licensed under the Creative Commons Attribution-NonCommercial-No Derivative Works 3.0 Unported License. To view a copy of this license, visit http:// creativecommons.org/licenses/by-nc-nd/3.0/ 